\title{
Environmental Negligence: A Proposal for a New Cause of Action for the Forgotten Innocent Owners of Contaminated Land
}

\author{
Melanie R. Kay†
}

\section{INTRODUCTION}

Imagine saving money to purchase a plot of land on which you plan to establish a business. You find the perfect location, make the investment, and set up and run your business. Sevcral years pass until one day, a government agency asks to do some soil testing on your land and finds a migrating underground plume of hazardous contamination below your property. You are told that the former owner of the property, a business owner himself, illegally dumped several barrels of toxic contaminants each year, either to avoid disposal fees or simply because he did not know he was doing anything wrong. The agency orders you to remediate the property, for there is danger that the contamination will migrate and infiltrate the local water supply. Agency officials threaten that if you do not act, they will initiate a formal cleanup charge against you under either a state or a federal environmental statute. At this point, you are probably shocked to discover that you have somehow become responsible for an incredibly expensive cleanup of pollution that you had no part in creating.

Unfortunately, this hypothetical is a reality for many landowners who purchased land before the modern awareness of environmental pollution's severe consequences. As a result, such landowners may not have taken advantage of protective techniques that are now common, such as contractual safeguards, environmental insurance, or expert environmental consultants who conduct extensive soil and groundwater testing. These landowners may have purchased their land directly from the polluting party, but in

Copyright (C) 2006 California Law Review, Inc. California Law Review, Inc. (CLR) is a California nonprofit corporation. CLR and the authors are solely responsible for the content of their publications.

$\dagger \quad$ J.D., School of Law, University of California, Berkeley (Boalt Hall), 2006. 1 would like to thank Robert $D$. Infelise for the engaging class discussion that inspired this comment. I would also like to thank Stephen D. Sugarman for his thoughtful reviews and excellent suggestions, which very much enhanced my research and writing experience. Finally, I would like to thank the staff of the California Law Review for all of their support and assistance. 
some cases they are separated from the original polluter by a line of innocent landholders. As I will explain, this "forgotten" class of landowners often finds itself blocked from any avenues of recovery, creating an unsatisfactory and unjust result.

As Part I explains, before the proliferation of federal environmental statutes in the late 1970s and early I980s, innocent owners of contaminated property in California turned to common law causes of action to recover the cost of remediation from former polluting landowners. Two causes of action-nuisance and trespass-were seen as potentially useful in this context because they were defined broadly in California. However, these causes of action were never intended to cover modern environmental disputcs, and their application was awkward and limited. As a result, with the advent of statutory schemes like the Comprehensive Environmental Response, Compensation, and Liability Act (CERCLA) ${ }^{1}$ and the Resource Conservation and Recovery Act (RCRA), ${ }^{2}$ many thought that common law actions for innocent landowners' environmental problems would die out altogether.

This did not occur, most likely because the statutes were no less restrictive than the common law. As Part II.A explains, CERCLA and RCRA contain numerous limits on a plaintiff's recovery, often resulting in substantial under-compensation. For example, CERCLA's petroleum exclusion completely eliminates this statute as a tool for any innocent landowner dealing with petroleum-based contamination-effectively barring a huge proportion of claims. In addition, CERCLA covers expenses only when they are directly related to cleanup; it will not cover lost rental value, property value diminution, or personal-injury costs. RCRA's remedies are limited to injunctions, so innocent landowners will find no monetary recovery through that avenue. Accordingly, most modern-day owners of contaminated property cobble together a combination of statutory and common law claims in an attempt to recover as much as they can.

As Part II.B shows, the nuisance and trespass claims cannot properly fill the holes left by CERCLA and RCRA. Unfortunately, this patchwork solution provided only partial recovery to innocent landowners. Clearly, it is unjust for the guiltless land purchaser to foot the (often incredibly expensive) bill for the cleanup of another's mess. Beyond that critical and obvious injustice, the current legal framework creates numerous inefficiencies that hinder the timely and complete cleanup of contaminated sites. Moreover, it does not take into account the unique particularities of environmental contamination, its assessment, and the proper methodologies for its removal.

1. 42 U.S.C. $\S \S 9601-9675(2000)$.

2. 42 U.S.C. $\$ \S 6901-6992(\mathrm{k})(2000)$. 
Although the federal statutes are rigid and permit only partial recovery, common law remedies need not share the same weaknesses. Rather than attempt to fit modern environmental contamination problems into archaic and ill-suited nuisance and trespass doctrines, Part III proposes a new negligence-based cause of action specifically tailored to the "innocent landowner." The proposed cause of action eliminates many of the restrictions and unnecessary confusion inherent in nuisance and trespass doctrine in an effort to modernize the landowner's common law options.

\section{I}

\section{Environmental Contamination: From the Common Law to a STATUTORY REgIME}

\section{A. Historical Use of Common Law Claims for Environmental Contamination}

The application of common law claims for nuisance and trespass to cases of environmental contamination is rooted in English common law. ${ }^{3}$ English courts in the thirteenth century recognized nuisance claims for smoke production and water diversion disputes. ${ }^{4}$ A nuisance case in the early 1600 s weighed the public benefit of a pigsty against the burden of the unpleasant odors on a neighbor; the case held that behavior rendering a neighboring household unlivable gives rise to a cause of action. ${ }^{5}$

In the United States, courts began recognizing toxic air pollution as a nuisance in the late $1800 \mathrm{~s}^{6}{ }^{6}$ Today, application of common law claims to environmental matters-and more specifically to present landowners' claims against former polluting owners-depends in large part on the breadth of state definitions of the claims. Many states rely on the definitions and elements of nuisance and trespass claims provided in the Restatement of Torts, which prohibits nuisance suits for pollution against prior owners.?

California, however, adopts a broader interpretation by defining a nuisance as "[a]nything which is injurious to health, ... or is indecent or offensive to the senses, or an obstruction to the free use of property, so as

3. G. Nelson Smith, III, Nuisance and Trespass Claims in Environmental Litigation: Legislative Inaction and Common Law Confusion, 36 SANTA ClaRA L. Rev. 39, 41-42 (1995).

4. W. Page Keeton et al., Prosser and Keeton on the Law of Torts $\S 86$, at 617 (5th ed. 1984).

5. William Aldred's Case, 77 Eng. Rep. 816 (K.B. 1611).

6. See Tom Kuhnle, The Rebirth of Common Law Actions for Addressing Hazardous Waste Contamination, 15 STAN. EnvtL. L.J. 187, 193 (I996) (citing cases).

7. Joseph F. Falcone IIl \& Daniel Utain, Comment, You Can Teach an Old Dog New Tricks: The Application of Common Law in Present-Day Environmental Disputes, 11 VILL. ENVTL. L.J. 59, 84 (2000). 
to interfere with the comfortable enjoyment of life or property." Courts have read this definition to imply two essential elements for the cause of action: first, that the condition caused by, or the activity of, the defendant has created substantial harm to the plaintiff; and second, that "the use of the property giving rise to the condition or activity at issue is an unreasonable one." Courts in California have further recognized that this "statutory definition of nuisance appears to be broad enough to encompass almost every conceivable type of interference with the enjoyment or use of land or property."10

In spite of the flexible statutory definitions, many commentators predicted the advent of fcderal statutory schemes like CERCLA and RCRA in the Iate I970s and early 1980s would render common law state claims relatively useless, ${ }^{11}$ for the statutes were specifically tailored to the environmental context and accommodated many complexities that the common law claims could not. However, as explained below, conspicuous gaps in and limitations of these federal schemes, as well as their lack of state common law preemption, have prompted most plaintiffs to rely on a combination of both federal statutory and state common law claims. ${ }^{12}$

\section{B. The Comprehensive Environmental Response, Compensation, and Liability Act and the Resource Conservation and Recovery Act}

The political climate and increasing environmental awareness in the 1970s and early I980s prompted Congress to enact a flurry of environmental statutes designed to address environmental contamination with more efficiency and predictability than the common law claims afforded. ${ }^{13}$ Between 1970 and 1977, Congress passed the Clean Air Act, ${ }^{14}$ the Clean Water Act, ${ }^{15}$ the Toxic Substances Control Act, ${ }^{16}$ and the Resource Conservation and Recovery Act (RCRA) ${ }^{17}$ to regulate and combat air pollution, water pollution, and hazardous waste land contamination. ${ }^{18}$ RCRA, enacted in 1976, primarily represented an attempt to reduce the production

8. CAL. CIV. CODE $\S 3479$ (West 1997). Trespass, though often grouped with nuisance, is narrower because it requires interference with the plaintiff's possession of his land. See Capogeannis v. Superior Court, 12 Cal. App. 4th 668, 674 (Cal. Ct. App. 1993).

9. Kuhnle, supra note 6 , at 195 (quoting Kenneth A. Manaster \& Daniel P. Selmi, California Environmental Law and Land Use Practices $\S 1.02[1]$, at 1-14 (1989 \& Supp. 1994)).

10. Mangini v. Aerojet-General Corp., 230 Cal. App. 3d 1125, 1136 (Cal. Ct. App. 1991) (quoting Stoiber v. Honeychuck, 101 Cal. App. 3d 903, 919 (Cal. Ct. App. 1980)).

11. Kuhnle, supra note 6 , at 214

12. See id.; Falcone \& Utain, supra note 7, at 63-64.

13. See Kuhnle, supra note 6. at 203-04; Smith, supra note 3, at 44-45.

14. 42 U.S.C. $\$ \S 7401-7671(2000)$.

15. 33 U.S.C. $\$ \S 1251-1387(2000)$.

16. 15 U.S.C. $\$ \S 2601-2692(2000)$.

17. 42 U.S.C. $\$ \S 6901-6992(k)$ (2000).

18. Smith, supra note 3 , at 44-45. 
of hazardous waste but also strove to better regulate its collection, handling, transport, treatment, storage, and disposal. ${ }^{19}$ In some instances, RCRA permits a private individual to bring a civil action for injunctive relief ${ }^{20}$ against "past or present owner[s] or operator[s] of a trcatment, storagc, or disposal facility, who [have] contributed or [are] contributing to the past or present handling, storage, treatment, transportation, or disposal of any solid or hazardous waste which may present an imminent or substantial endangerment to health or the environment."21

Despite these attempts to combat the environmental threats of the day, in 1980, Congress decided that "[e]xisting law is clearly inadequate to deal with [the] massive problem"22 of large-scale environmental contamination (as illustrated by such high-profile sites as Love Canal), and it enacted the Comprehensive Environmental Response, Compcnsation, and Liability Act (CERCLA) ${ }^{23}$ CERCLA allows those who incur costs cleaning up environmental contamination to obtain reimbursement from parties associated with the pollution's creation. ${ }^{24}$ CERCLA contains intricate definitions and limitations on who may recover, the activities and substances that constitute a release of a hazardous substance, who falls within the chain of liability, and the type of costs that may be recovered. ${ }^{25}$ Liable parties then either reimburse the party that incurred response costs (so long as those costs are consistent with strict cleanup guidelines) through monetary damages, or they are enjoined to work with the EPA to develop an approved cleanup methodology. The CERCLA requirements do not lend themselves to swift action-on average, eight years pass between the initial recognition of a CERCLA claim and the commencement of a cleanup. ${ }^{26}$

II

\section{Moving Toward a New Cause of Action}

Despite the admirable goals of the environmental statutes, Part II.A demonstrates that exceptions and limitations built in to the statutes reduce their effectiveness for potential plaintiffs. As a result, the common law options, unhindered by the same exclusions and restrictions, have become

19. See 42 U.S.C. $\$$ 6902; Robert J. Gaglione, Perspective: Can a Private Party Recover Future Clean-Up Costs Under RCRA?, 19 T. JEFFERSON L. Rev. 91, 93-94 (1997).

20. See Meghrig v. KFC W., 516 U.S. 479 (1996); Gaglione, supra note 19, at 91. Meghrig settled a split between the Eighth and Ninth Circuits, eliminating RCRA as a mechanism for private citizens to recover past costs from hazardous waste cleanups. The availability of future cleanup cost recovery technically remains open but unlikely. See Gaglione, supra note 19, at 96-97.

21. 42 U.S.C. $\$ 6972(a)(1)(B)$.

22. Kuhnle, supra note 6, at 189 (quoting H.R. Rep. No. 96-1016, 96th Cong., 2d Sess. 22 (1980), reprinted in 1980 U.S.C.C.A.N 6119, 6120).

23. 42 U.S.C. $\$ \S 9601-9675$ (2000).

24. Id. $\$ 9607$.

25. Id. \$9601.

26. See Kuhnle, supra note 6, at 207. 
increasingly attractive, as Part II.A.3 explains. However, their greater flexibility notwithstanding, the common law causes of action remain a lessthan-ideal option for modern-day environmental contamination disputes, largely because the claims did not evolve with highly technical environmental cleanup scenarios in mind, as Part II.B details. As a result, there remains no ideally applicable method for plaintiffs to achieve efficient and complete recovery.

\section{A. TheLlimits of the Environmental Statutory Options}

\section{Limitations of CERCLA}

Numerous aspects of CERCLA make the statute less effective than its aspirations suggest. First, CERCLA contains a petroleum exclusion which probably has the greatest limiting effect on the statute's ability to fully address hazardous waste contamination. That is, CERCLA's definition of "hazardous waste" specifically excludes "petroleum, including crude oil or any fraction thereof which is not otherwise specifically listed or designated a hazardous substance... and the term does not include natural gas, natural gas liquids, liquefied natural gas, or synthetic gas usable for fuel."27 This broad exclusion, a last-minute political compromise, ${ }^{28}$ completely eliminates any form of petroleum-derived contamination from CERCLA's protective umbrella. Considering the vast national problem of leaking underground petroleum storage tanks, ${ }^{29}$ CERCLA fails to address many dangerously contaminated sites.

Victims of petroleum-based contamination from leaking tanks do have a potential statutory ally in RCRA. Unlike CERCLA, RCRA defines "solid or hazardous waste" to include discarded or abandoned material, which the district court in Zands v. Nelson ${ }^{30}$ determined includes leaking material. ${ }^{31}$ The court noted the broadly intended definition of "solid waste" and held that gasoline that has leaked into and mixed with soil properly fulfills the definition. ${ }^{32}$ Under this interpretation, RCRA serves as a gapfiller, covering a broad category of contaminated sites excluded from CERCLA's coverage. However, the remedies available through RCRA are more limited than those afforded by CERCLA: while the successful RCRA litigant may obtain an injunction against the defendant, the statute does not

27. 42 U.S.C. $\$ 9601(14)$.

28. See Marcia L. Peterson, Note, Hazardous Waste-The Supreme Court's Interpretation of RCRA: An Inequitable Result, 32 LAND \& WATER L. REv. 699, 707, 715 (1997) (citing Daniel L. McKay, RCRA's Oil Field Wastes Exemption and CERCLA's Petroleum Exclusion: Are They Justified?, 15 J. ENERGY NAT. Resources \& EnVtL. L. 41 (1995)).

29. See id. at 716 .

30. 779 F. Supp. 1254 (S.D. Cal. 1991).

31. Id. at 1261-62.

32. See id. at 1262. 
include a monetary-damages provision. ${ }^{33}$ Thus, for the plaintiff who desires remedies beyond RCRA's injunctive relief for sites of petroleum-based contamination, the common law route provides the only promising avenue for obtaining monetary damages.

Second, CERCLA awards damages only to cover the costs of cleanup incurred in strict compliance with CERCLA site cleanup guidelines, known as the National Contingency Plan (NCP) ${ }^{34}$ While the statute assumes that government cleanups comply with the NCP unless proven otherwise, the plaintiff who privately undertakes cleanup and later seeks restitution bears the burden of proof that the cleanup conformed to the NCP standards ${ }^{35}$ As the Ninth Circuit held in Washington State Department of Transportation v. Washington National Gas Co. ${ }^{36}$ this requirement is based on the rationale that parties seeking reimbursement for cleanup costs should comply with guidelines designed to ensure cost-effective, reliable cleanup measures. ${ }^{37}$

Washington National Gas Co. demonstrates the high standard that CERCLA demands. In that case, the court determined that even though the Washington DOT could be considered a "state" and could therefore be given the presumption of NCP compliance as per the statute, the agency had not conformed to the guidelines. ${ }^{38}$ Washington Department of Transportation (DOT) had hired an environmental consultant to ascertain the extent of contamination and fully remediate the site. ${ }^{39}$ The consultant did not comply with the NCP and significantly underestimated the magnitude of contamination. ${ }^{40}$ Eventually, despite these problems, Washington DOT eventually cleaned the site fully, spending $\$ 4,550,000$ in the process. ${ }^{41}$ Despite these substantial unanticipated costs, the DOT was unable to recover from the defendant gas company that had caused the contamination because of the consultant's failure to comply with the NCP..$^{42}$

While it would be unfair for a defendant to cover extra cleanup costs that result from a plaintiff's mishandling of remediation, it is even more unfair for a plaintiff to bear the full financial burden of a defendant's remediation by luck of a consultant's mistakes. Common law claims can provide plaintiffs who do not strictly adhere to NCP guidelines with other methods to recover. While CERCLA will not permit a plaintiff to doubly

\footnotetext{
33. 42 U.S.C. § 6972(a)(2); see also supra note 20 for an explanation of RCRA's monetary recovery limitations.

34. 40 C.F.R. $\S 300.70$ (c)(3)(i) (1994).

35. See 42 U.S.C. $\S 9607$ (a)(4)(A)-(B).

36. 59 F.3d 793 (9th Cir. 1995).

37. Id. at 802 .

38. Id. at 802-05.

39. Id. at 797 .

40. Id. at 803 .

41. Id. at 798 .

42. Id. at 805 .
} 
recover the same costs by using both CERCLA and state law claims, ${ }^{43}$ presumably a plaintiff may still seek redress for costs not covered by CERCLA through use of state common law.

Third, CERCLA limits injunctive relief to government entities attempting to stop defendants from "an actual or threatened release of a hazardous substance from a facility" where the EPA "determines that there may be an imminent and substantial endangerment to the public health or welfare or the environment." 44 Private parties cannot obtain such an injunction. Additionally, neither a government agency nor a private party may seek an injunction against a defendant for post-contamination cleanup after the polluting activities have ceased.

Fourth, CERCLA limits reimbursement of costs to those expended in accordance with the NCP, and it limits monetary recovery by private parties to the "necessary costs of response." 45 Therefore, plaintiffs may not recover losses incurred as a consequence of, but not necessarily in response to, the contamination; for example, they cannot recover lost rental value, diminution in property value, lost business income, personal injury costs, or attorney fees. ${ }^{46}$ A plaintiff may not recover punitive damages from a polluting defendant under CERCLA unless the defendant violated an administrative order. ${ }^{47}$ CERCLA thus typically offers a plaintiff incomplete recovery of the significant expenses related to cleanup of a site contaminated by another party. A plaintiff who seeks to be "made whole" must turn to other options, such as state common law claims.

Finally, a recent Suprcme Court case illustrates yet another limitation of CERCLA for those who seek restitution for cleanup of contaminated sites. In Cooper Industries $v$. Aviall Services, ${ }^{48}$ the Court expounded upon section 1 I 3 of CERCLA, which allows parties held liable for response costs to seek contribution from other potentially liable parties. Aviall had purchased four aircraft maintenance sites in Texas from Cooper, realizing only later that Cooper had contaminated the sites during its ownership. ${ }^{49}$ Because leaking underground tanks and spills continued during Aviall's ownership, however, Aviall also contributed to the contamination. ${ }^{50}$ Aviall disclosed the pollution to the Texas Natural Resource Conservation

43. 42 U.S.C. $\S 9614(\mathrm{~b})$.

44. Id. § 9606(a); see also New York v. Shore Realty Corp., 759 F.2d 1032, 1049 (2d Cir. 1985) (denying injunctive relief to the State under CERCLA and explaining the intended use of injunctive relief in CERCLA's drafting).

45. 42 U.S.C. $\$ 9607(a)(4)(B)$.

46. Kuhnle, supra note 6, at 209-10 (citing Key Tronic Corp. v. United States, 511 U.S. 809 (1994)); Exxon v. Hunt, 475 U.S. 355, 359 (1986); Wehner v. Syntex Corp., 681 F. Supp. 651, 653 (N.D. Cal. 1987).

47. Kuhnle, supra note 6, at 210.

48. 125 S. Ct. 577 (2004).

49. Id. at 582 .

50. Id. 
Commission, which threatened an enforcement action should Aviall neglect to clean the site. ${ }^{51}$ Aviall then fully cleaned the property, incurring $\$ 5$ million in costs, and neither the State nor the EPA took official enforcement action. ${ }^{52}$ Aviall then sought contribution for cleanup costs from Cooper under section 113.

The Court held that since Aviall had not itself been sued under CERCLA, it could not utilize section 113, a provision reserved exclusively for parties to CERCLA lawsuits. ${ }^{53}$ Because Aviall voluntarily cleaned the contaminated sites before the government brought a CERCLA action, the Court held that Aviall had no right to seek contribution for its costs from Cooper under section 113. Like other limitations of CERCLA, Cooper Aviall highlights the importance of state common law claims to effect a fair distribution of liability.

\section{Limitations of $R C R A$}

RCRA, like CERCLA, also limits a plaintiff's potential recoveries, further magnifying the need to pursue multiple causes of action. Most importantly, RCRA limits its relief to injunctions, ${ }^{54}$ denying the plaintiff monetary reimbursement of any cleanup-related expenditures or economic losses. Additionally, before allowing recovery, RCRA requires that offending materials constitute a "solid or hazardous waste which may present an imminent and substantial endangerment to health or the environment." 55 Restrictive judicial interpretations of this requirement limit RCRA's utility for owners of undeveloped or remote property. For example, in United States $v$. Reilly Tar \& Chemical Corporation, ${ }^{56}$ a district court cited the legislative history in the House Committee Report accompanymg the Safe Water Drinking Act to demonstrate that the intended meaning behind "imminent and substantial endangerment" was the protection of public health through action swift enough to "prevent the potential hazard from materializing." " B7 ny narrowing the realm of actionable endangerment to public harm, the court implied that environmental contamination in unpopulated areas with little or no anticipated effect on the public might not be sufficient to invoke injunctive action under RCRA. This limitation would eliminate RCRA as a source of relief for a plaintiff owning remote property.

51. Id.

52. Id.

53. See id. at 583-84

54. 42 U.S.C. $\S 6972(a)(2)$; see supra note 20 for a discussion of RCRA's limited ability to cover monetary damages.

55. 42 U.S.C. $\S 6972(a)(1)(B)$ (emphasis added); see also 42 U.S.C. $\S$ 6973(a) (explaining the "imminent and substantial endangerment" standard for suits brought by the Administrator, as opposed to private citizen suits as addressed in $\$ 6972$ ).

56. 546 F. Supp. 1100 (D. Minn. 1982).

57. Id. at 1109 (emphasis added). 
A second limitation arising from the same "imminent and substantial endangerment" requirement is that RCRA might not provide injunctive relief for contamination that has become encapsulated such that further migration is unlikely. In Price v. United States $N a v y,{ }^{58}$ for instance, the Navy contaminated with heavy metals and asbestos property that was later residentially developed. ${ }^{59}$ Price discovered the contamination during a pool excavation and subsequently moved into a relative's home for fear of harm to her family's health.$^{60}$ Price then spent over $\$ 30,000$ to remove contaminated soil from the property, as required by official notice. ${ }^{61}$ The State later determined that the site presented an "imminent and substantial endangerment" to public health, and it undertook a large-scale cleanup of the general vicinity. ${ }^{62}$ Price then filed an RCRA claim against the Navy requesting cleanup of contaminated soil not removed by the government from under the foundation of her house; ${ }^{63}$ she claimed that because of structural deficiencies in her house's foundation, the contamination could migrate and expose her family to harm. ${ }^{64}$ The court determined, however, that because the concrete foundation, albeit cracked, should provide an effective barrier between the house and any contamination, the harm was neither substantial nor imminent; accordingly, Price was not entitled to a RCRA injunction against the Navy. ${ }^{65}$ Additionally, because CERCLA does not cover medical expenses, attorney fees, property value diminution, or relocation costs, Price recovered none of these losses.

\section{Advantages of Common Law Claims}

\section{a. Advantages over the Statutory Solutions}

Common law claims hold important advantages for plaintiffs seeking compensation in environmental contamination suits. First, definitional exclusions, like the petroleum exclusion in CERCLA, are not a factor in common law claims; plaintiffs are not barred from suit simply because their land is contaminated by the wrong pollutant. Second, common law claims do not share RCRA's restrictive "imminent or substantial endangerment" to public health requirement. Third, unlike CERCLA and RCRA, common law suits do not restrict remedies to either damages or injunctions, and they do not require costs to be incurred according to any specific guidelines. Economic losses such as lost rental value, diminution

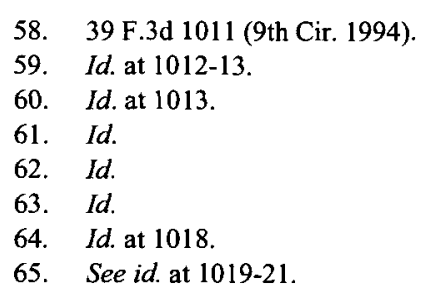


in property value, personal injury or medical expenses, attorney fees, relocation costs, business losses, and even punitive damages are all available through the common law. The free-form nature of common law claims affords plaintiffs flexibility not available under either CERCLA or RCRA. The combination of statutory and common law claims is therefore crucial to the plaintiff who seeks full recovery.

Luckily, the drafters of both CERCLA and RCRA anticipated and encouraged the use of state common law tort claims for recovery of losses not available using the statutory methods. CERCLA states that "[n]othing in this Act shall be construed or interpreted as preempting any State from imposing any additional liability or requirements with respect to the release of hazardous substances within such State. ${ }^{966}$ Additionally, CERCLA has been construed in several cases as not preempting personal injury, economic losses, or property damage claims resulting from contamination prior to a CERCLA cleanup. ${ }^{67}$ RCRA also includes a savings clause which states that "[n]othing in this section shall restrict any right which any person (or class of persons) may have under any statute or common law to seek enforcement of any standard or requirement relating to the management of solid waste or hazardous waste, or to seek any other relief (including relief against the Administrator or a State agency)." ${ }^{968}$

\section{b. Advantages over Actions in Contract}

Common law claims in tort also provide benefits over attempts at recovery through actions in contract. Because of the assumption that parties have the opportunity to negotiate before entering contractual agreements, most courts apply the doctrine of caveat emptor to contractual relationships. The Third Circuit strictly adhered to this principle in Philadelphia Electric Co. v. Hercules, Inc. ${ }^{69}$ in barring recovery of cleanup costs in a private nuisance action to an environmental contamination plaintiff who had unknowingly purchased contaminated industrial property. The court believed that any concession to the plaintiff for after-purchase discovery of pollution in the absence of fraud or concealment would disrupt delicate market balances and risk allocation between sophisticated sellers and purchasers. ${ }^{70}$ Despite almost uniform acceptance of this holding, ${ }^{71}$ in Newhall

66. 42 U.S.C. $\$ 9614(a)(2000)$.

67. Gregory M. Romano, "Shovels First and Lawyers Later": A Collision Course for CERCLA Cleanups and Environmental Torts Claims, 21 WM. \& MARY ENVTL. L. \& POL'Y REv. 421, 438-39 (1997), citing Edward Hines Lumber Co. v. Reilly Tar \& Chem. Corp., 685 F. Supp. 651 , 657 (N.D. Ill. 1988); Artesian Water Co. v. New Castle County, 851 F.2d 643, 648-49 (3d Cir. 1988); Attorney General v. Thomas Solvent Co., 380 N.W.2d 53, 59 (Mich. Ct. App. 1985).

68. 42 U.S.C. $\$ 6972(f)(2000)$.

69. 762 F.2d 303 (3d Cir. 1985).

70. Id. at $314-15$.

71. Andrew R. Klein, Hazardous Waste Cleanup and Intermediate Landowners: Reexamining the Liability-Based Approach, 21 HARv. ENvTL. L. REv. 337, 359 (1997). 
Land Farming Co. v. Superior Court ${ }^{72}$ California took a different approach by acknowledging an exception to caveat emptor for latent defects; that is, liability may be imposed on a seller who fails to disclose a hidden defect that may pose an unreasonable risk of physical harm to the purchaser, who was unlikely to discover the defect through normal inspection of the property. ${ }^{73}$

Potential application of the latent-defect exception notwithstanding, two problems remain with actions in contract for environmental contamination problems. First, privity between the original polluter and the current owner often will not exist. It is quite probable in cases of slowly leaking or long-buried contaminants that the first purchaser of the property after contamination will have no knowledge of the pollution. That purchaser may then sell the land to a second owner, and so forth. The discovery of the pollution might not occur until much later in the purchasing chain. In this situation, the current owner does not desire a remedy from the most recent seller. Rather, notions of fairness suggest the action is best directed against the original polluter. ${ }^{74}$ An action in contract will not offer any help to this current owner, as there is no contract on which to bring an action against the original polluter. Suing up the chain from purchaser to prior purchaser until the polluter is finally reached also seems an inefficient means to obtain recovery, compared to the simplicity of a direct action against the original polluter.

Second, while a current owner who had knowledge of and consented to the contamination at the time of purchase should not obtain a windfall by receiving recovery for the pollution, there remain shades of gray between absolute consent and complete ignorance. For example, in Beck Development Co. v. Southern Pacific Transportation Co. ${ }^{75}$ Southern Pacific sold land with an obvious oil reservoir to a purchaser who tore it down and buried it. While the second purchaser was aware of the reservoir's existence, after twenty-five years of farming and subsequent sale to Beck, a developer, he had forgotten about it. When Beck attempted to obtain recovery from Southern Pacific, the court held that the first purchaser's "consent" to the pollution precluded later purchasers from suit. ${ }^{76}$ This raises the problem of behavior by purchasers that may be deemed

72. 19 Cal. App. 4th 334 (Cal. Ct. App. 1993). The court allowed a subsequent purchaser of contaminated land to bring claims of nuisance, trespass, and negligence against a former owner who had illegally polluted the property without disclosing the eontamination to purchasers. The court noted that the purchaser was unaware of the undisclosed contamination and had no information that would give him reason to discover the defect.

73. Restatement (SeCond) of Torts $§ 353$ (1965).

74. Unless, of course, the owners since the pollution knew of the eontamination and concealed this information from the purchaser. In this case, it seems more equitable for the current owner to seek a remedy from both the polluter and the later seller.

75. 44 Cal. App. 4th 1160 (Cal. Ct. App. 1996).

76. Id. at 1216 . 
"consent," a critical issue for landowners who may be in contractual privity with the original polluter. As mentioned, sales made in the era before modern awareness of environmental contamination's severity might not fully have accounted for pollution's devastating effects in the bargaining process, and purchasers may not have adequately protected themselves through insurance or expert testing before purchase. Old "as-is" contracts might not have been crafted with a full understanding of the consequences. Confusion can always exist, even in modern contracts, in understanding waivers or releases of rights of purchasers. In fairness, if a seller provided clear writing or disclosure of the pollution, the purchaser should not later be permitted to claim lack of consent. ${ }^{77}$ However, for contracts crafted before the current sophisticated undcrstanding of environmental contamination, strict adherence based on a purchaser's consent might not always produce the most equitable or efficient result. ${ }^{78}$

\section{B. Common Law Claims of Nuisance and Trespass: An Awkward Fit for Environmental Contamination Disputes}

Despite their advantages over statutory and contractual remedies, nuisance and trespass causes of action are an imperfect match for environmental contamination suits. The problems arise primarily from attempts to extend the constraints of traditional torts to modern situations not envisioned during the development of tort doctrine. The use of nuisance and trespass causes of action for environmental contamination sites, although often the best hope for plaintiffs, is in essence an attempt to shove a square peg into a round hole.

77. The adequacy of warnings is a frequently contested issue in itself. See, e.g., Stevens v. Park, Davis \& Co., 507 P.2d 653 (Cal. 1973) (discussing the adequacy of prescription-drug warnings).

78. For a thorough description of both the Beck decision and detailed discussion of consent issues in contract for contaminated sites, see Joseph J. Ybarra, Refining California's "Consent" Defense in Environmental Nuisance Cases: Determining the Proper Scope of Liability for Responsible Former Owners, 74 S. CAL. L. REv. 1191, 1206-22 (2001). 


\section{Details of Nuisance and Trespass Claims}

Much of the problem with extending California's traditional tort claims into the environmental context results from definitional constraints that have developed in case law. This Section considers some formal distinctions that California's tort law draws. The subsequent Part elaborates how these definitional constraints can affect environmental contamination plaintiffs.

\section{a. Public Versus Private}

In California, a public nuisance is "one which affects at the same time an entire community or neighborhood, or any considerable number of persons, although the extent of the annoyance or damage inflicted upon individuals may be unequal."79 A private nuisance is simply "[e]very nuisance not included in the definition" of a public nuisance. ${ }^{80}$ In practice, any infringement of the rights of the public at large constitutes a public nuisance; a private right of action arises only when a private plaintiff suffers a harm "different in kind," not just greater in degree, than the harm suffered by the general public. ${ }^{81}$

Thus, in Mangini $v$. Aerojet-General Corp. ${ }^{82}$ the plaintiffs were able to initiate a private action against the polluting defendants for a public nuisance because the government required plaintiffs to hire consultants to undertake contamination testing on their land-an injury "different in kind" from that suffered by the general public. ${ }^{83}$ In contrast, a purely private nuisance typically involves a direct interference with plaintiff's use and enjoyment of his or her privately owned land. ${ }^{84} \mathrm{~A}$ neighbor operating a factory on adjoining property that results in disruptive smoke and noise is a classic example of a private nuisance.

Trespass can also be divided into public and private claims, both of which require actual touching of plaintiff's property to satisfy the definition of trespass. ${ }^{85}$ A similarly classic example of a private trespass is a neighbor dumping waste on another's adjoining property.

\section{b. The Neighboring Limitation}

As these examples of private nuisance and trespass demonstrate, courts have traditionally assumed that injury to a plaintiff's land must

79. Cal. Civ. Code $\S 3480$ (West 1997).

80. Id. § 3481 .

81. See Restatement (Second) of Torts $\S 821$ (C) cmt. b (1979); Cal. Civ. Code $\$ 3493$.

82. 230 Cal. App. 3d 1125 (Cal. Ct. App. 1991).

83. Id. at 1137-38.

84. See KEETON ET AL., supra note $4, \S 86$, at 617-19.

85. See Restatement (SECOND) OF TorTs $§ 158$ (1965). 
originate from a neighboring land parcel in order to invoke the private nuisance and trespass causes of action. ${ }^{86}$ Citing numerous treatises and opinions in support of this premise, the defendants in Mangini argued that contamination of a plaintiff's land by former owners could not constitute a nuisance or trespass because the pollution originated on the same piece of property rather than coming from a neighboring plot and because the former tenants had obviously permitted the dumping to occur. ${ }^{87}$ That is, the defendants suggested that one cannot create a nuisance or trespass on one's own property, even if the harmful consequences of one's actions affect a subsequent owner.

The California Court of Appeals rejected this argument, however, holding that as a result of California's broad statutory definition of "nuisance," a nuisancc dispute need not involve neighboring land parcels. ${ }^{88}$ The court explained that the various authorities the defendant cited "do not correctly reflect California law" because in California, "nuisance law is a creature of statute" and has been read to "allow an owner of property to sue for damages caused by a nuisance created on the owner's property." 89 Additionally, the court found that a defendant's lease did not "give defendant unrestricted possession of the land" and therefore gave the defendant no right to dump waste on the property. Thus, the claim for trespass could continue even though the dumping occurred on the same, rather than a neighboring, piece of land..$^{90}$ This interpretation represents a key advantage to land contamination plaintiffs in California who purchase or lease property polluted by previous lessees.

The Mangini court's interpretation has been limited, however, in other factual settings. In Capogeannis v. Superior Court ${ }^{91}$ for example, the court rejected a trespass claim against prior owners of the contaminated land purchased by plaintiffs because the owners had not been subject to any restrictions in the use of the land. ${ }^{92}$ However, the court in Newhall Land \& Farming Co. v. Superior Court ${ }^{93}$ later called the reasoning in Capogeannis into question and allowed a trespass claim based on similar facts to stand, holding that defendant's creation of a public nuisance-in this case contamination of the land-constituted a continuous trespass under the Restatement (Second) of Torts. ${ }^{94}$ This complicated series of outcomes

\footnotetext{
86. Falcone \& Utain, supra note 7, at 66.

87. Mangini, 230 Cal. App. 3d at 1 133-34.

88. Id. at 1134 .

89. Id.

90. Id. at 1141 .

91. I2 Cal. App. 4th 668 (Cal. Ct. App. 1993).

92. Id. at 674 .

93. I9 Cal. App. 4th 334 (Cal. Ct. App. 1993).

94. See id.at $345-47$.
} 
raises much confusion for the environmental contamination plaintiff in evaluating litigation strategy and the probability of a favorable result.

\section{c. Permanent Versus Continuing}

California's tort law also distinguishes between permanent and continuing nuisances and trespasses based on whether pollution can be easily abated. ${ }^{95}$ Contamination so extensive and pervasive that it is financially and practically unreasonable to attempt remediation is considered permanent, ${ }^{96}$ whereas reasonably or practically abatable pollution is considered continuing. ${ }^{97}$ The creation of noise or smoke, for example, constitutes a continuing nuisance, for the disruption can reasonably be stopped; ${ }^{98}$ the construction of a public utility building that partially extends onto neighboring land would be categorized as a permanent nuisance, for it is unreasonable to tear down the building in order to offer relief to the plaintiff. ${ }^{99}$ Unfortunately, the line between permanent and continuing nuisances is not often easy to draw. In cases that ride the fine line between permanent and continuing nuisances, plaintiffs may proceed under whichever classification they choose, ${ }^{100}$ with courts tending to classify harms as continuing instead of permanent in close cases to avoid the sometimes harsh implications of a determination of permanency. ${ }^{101}$ This lack of clarity and predictability is unfortunate, for the permanent/continuing classification has important ramifications.

First, the type of recovery afforded the nuisance or trespass plaintiff varies depending on the classification. The damagcs awarded for a permanent nuisance or trespass are intended to serve as a "one-time payment" for all past, present, and future harm suffered by the plaintiff as a result of the injury, and the plaintiff is estopped from subsequent actions arising from the same incursion. ${ }^{102}$ This forces the plaintiff to attempt to estimate all future harm that will result from the nuisance or trespass-a calculation often resulting in substantial under-recovery due to short-sightedness or incomplete information. ${ }^{103}$ Additionally, because the payment is "one-time only," the defendant has no incentive to abate the nuisance or trespass since he is in effect paying for the privilege of indefinitely continuing the

95. Robert E. King, Chemical Contamination in California: A Continuing Nuisance?, 1997 U.

Chi. Legal F. 483, 485 (1997).

96. Id.

97. Mangini v. Aerojet-General Corp. (Mangini III), 12 Cal. 4th 1087, 1087 (1996).

98. See King, supra note 95 , at 485 .

99. See Spaulding v. Cameron, 38 Cal. 2d 265, 267 (1952).

100. Id. at 268 .

101. See, e.g., United States v. Dickinson, 331 U.S. 745, 749 (1947); Baker v. Burbank-Glendale-

Pasadena Airport Auth., 39 Cal. 3d 862, 870 (1985); Capogeannis, 12 Cal. App. 4th at 678.

102. Baker, $39 \mathrm{Cal}$. 3d at 869.

103. See Capogeannis, 12 Cal. App. 4 th at 678-79. 
injurious behavior. ${ }^{104}$ In contrast, a plaintiff in a continuing nuisance or trespass action may bring consecutive actions for recovery until the defendant ceases the behavior giving rise to the claim, for every new occurrence of the nuisance or trespass creates a new and separate right of action. ${ }^{105}$ However, the plaintiff may receive damages to compensate only for injuries sustained up to the time of the suit; on the theory that the defendant may cease the injurious behavior at any time, no future or prospective damages are permitted. ${ }^{106}$

Second, the characterization as permanent or continuing determines the statute of limitations applied to the plaintiff's cause of action. A suit for a private or public permanent nuisance or trespass is subject to a three-year statute of limitations in California. ${ }^{107} \mathrm{~A}$ continuing nuisance or trespass, however, entitles the plaintiff to a renewal of the statute of limitations with each injury, ${ }^{108}$ often creating a virtually unlimited timeframe in which to sue. However, the plaintiff may only request damages sustained during the three years preceding the current injurious activity. The classification of a nuisance or trespass as permanent or continuing therefore has a large effect on the success of a plaintiff's claim, for a "permanent" determination can often result in a complete time-barring of the action.

\section{Not All Contamination Scenarios Fit Within the Definitions}

Though California's broad definitions of nuisance and trespass can encompass many environmental contamination scenarios, some pollution situations remain an imperfect or awkward fit. For example, the lack of agreement between Capogeannis and Newhall on the "neighboring" limita$\operatorname{tion}^{109}$ suggests that trespass actions may not be successful when the former owner willfully contaminated his own land. Moreover, the Restatement (Second) of Torts suggests that if a prior owner created a public nuisance, the current owner has no private right of action unless he can establish that he suffered a specialized injury different in kind, not just greater in magnitude, than that suffered by the general public. ${ }^{10}$ Although Mangini states that plaintiff's testing costs constitute such a specialized injury, ${ }^{111}$ it is still unclear whether cleanup costs also suffice. The inability to recover costs incurred from simply cleaning, rather than testing, a site could prohibit numerous plaintiffs from suing and recovering under a public nuisance theory. Although common law claims encompass a broad array of

\footnotetext{
104. See id.

105. Phillips v. City of Pasadena, 27 Cal. 2d 104, 107-08 (1945).

106. Baker, 39 Cal. 3 d at 869.

107. Cal. Civ. Proc. Code $\S 338$ (West 1982).

108. Kuhnle, supra note 6, at 197.

109. See Part 11.B.1.b, supra.

110. See Resta tement (SECOND) OF TorTs $\$ 821$ (C) cmt. b (1979).

111. Mangini, 230 Cal. App. 3d at 1138.
} 
contamination scenarios, some plaintiffs are still likely to fall through the cracks, as this Section demonstrates.

\section{a. Distinguishing "Continuing" and "Permanent"}

Courts have employed various tests and standards in an attempt to apply the "continuing" and "permanent" classifications to real-world environmental problems, often with inconsistent results. Before Capogeannis, some courts applied literal abatability tests in an attempt to determine which encroachments were truly incapable of removal or remediation. ${ }^{112}$ Courts struggled in their attempts to define "abatable," often resorting to vague totality-of-the-circumstances approaches. ${ }^{113}$ As stated in Spar $v$. Pacific Bell, ${ }^{114}$ "[c]lear-cut distinctions between permanent and temporary nuisances are elusive at best.".115

The difficulty of distinguishing permanent from continuing nuisance using literal definitions explains a long history of seemingly inconsistent opinions. In Baker v. Burbank-Glendale-Pasadena Airport Authority, ${ }^{116}$ the California Supreme Court deemed noise and vibrations emanating from a public commercial airport a continuing nuisance despite the size, cost, and public utility of the source. ${ }^{117}$ The Spar court, on the other hand, classified a public utility's underground wires as a permanent nuisance despite the fact that they had been rcmoved by the defendant-and thus were obviously removable. ${ }^{118}$ These incongruous results highlight the unpredictability that an environmental contamination plaintiff faces when litigating an environmental contamination claim for nuisance or trespass.

In Field-Escandon v. DeMann, ${ }^{119}$ the court embraced a "varying impact over time" test to distinguish a continuing from a permanent nuisance or trespass. ${ }^{120}$ The court in The Stanley Works v. Snydergeneral Corporation $^{121}$ applied this tcst, finding an underground TCE contaminant plume a continuing nuisance due to its migration and growth, despite the fact that the contamination was several hundred feet wide and a hundred feet deep-seemingly too large for easy remediation. ${ }^{122}$ Later, the court in Mangini III $I^{123}$ applied a different "practically abatable" test developed in

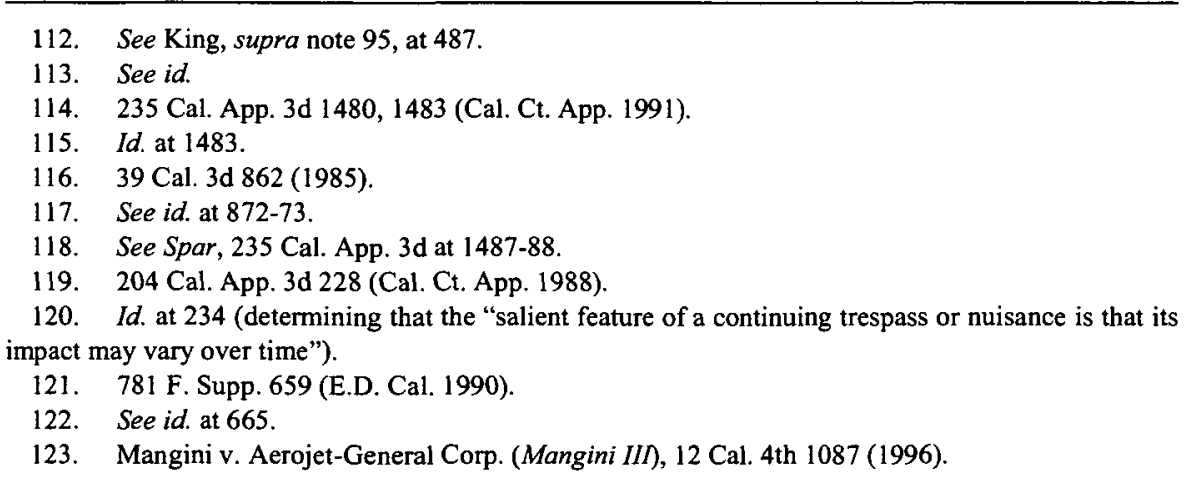


Capogeannis $^{124}$ to find that an underground, migrating plume of toxic waste constituted a permanent nuisance because plaintiffs knew neither the full extent of the contamination nor the expected costs of cleanup. ${ }^{125}$

\section{b. The Consequences of Continuing or Permanent Classifications}

The lack of predictability as to whether a court will treat contamination as continuing or permanent causes numerous problems and disadvantages for the plaintiff. The statute of limitations is probably the most important consequence of the continuing/permanent classification. When the court considers the plaintiff's nuisance or trespass to be permanent, a three-year statute of limitations applies. ${ }^{126}$ Because of the typically long intervals that pass before plaintiffs are able to discover contamination on their property, plaintiffs' claims are often dismissed as time-barred even though the plaintiff did not delay in bringing suit. The statute of limitations in nuisance and trespass actions does not wait to begin until the time that the nuisance or trespass was discovered. ${ }^{127}$ In the environmental context, where leaking underground tanks or slowly migrating contaminant plumes are common yet invisible threats, requiring plaintiffs to sue within three years of the contamination is unjustly rigid.

Because the classification of a trespass or nuisance as "permanent" bars so many claims, plaintiffs often need to ensure that the court designates the contamination as continuing to secure any chance at recovery. However, to earn a "continuing" status, the site's contamination must be fully ascertainable and reasonably abatable. In Mangini III, after all, plaintiffs were denied a continuing classification because cleanup costs and the full extent of contamination were vague and potentially massive. ${ }^{128}$ In reaction to Mangini III, plaintiffs often attempt to underplay the magnitude of the pollution so that the court will consider it abatable and thus "continuing." Plaintiffs are therefore presented with an odd set of incentives. On one hand, the plaintiff wants to present the complete picture of all of the losses associated with the contamination so as to achieve full recovery. On the other hand, if the plaintiff does too good of a job showing the high costs associated with remediation and the extensive nature of the pollution, the court may deem the contamination so great and the cleanup so expensive that it is considered "permanent" and potentially time barred.

124. See Capogeannis v. Superior Court, 12 Cal. App. 4th 668, 678 (Cal. Ct. App. 1993) ("Regardless of literal abatability, where as a practical matter either abatement or successive lawsuits would be inappropriate or unfair then the nuisance may be regarded as permanent ....").

125. See Mangini III, 12 Cal. 4th at 1096-1104.

126. See Cal. Civ. Proc. Code $\S 338$ (West 1982).

127. Albert C. Lin, Application of the Continuing Violations Dactrine to Environmental Law, 23 Ecology L.Q. 723, 729 (1996).

128. See Mangini III, 12 Cal. 4th at 1098-1103. 
Plaintiffs may, accordingly, often underestimate their own losses in order to ensure at least a partial recovery.

In cases where plaintiffs are permitted to choose between continuing and permanent designations, there frequently is no real choice; often the plaintiff must proceed on a continuing theory because the three-year statute of limitations for permanent trespass or nuisance has already run. Because a continuing classification implies that the losing defendant will remediate the property rather than simply pay for the continued presence of the contamination, the damages are limited to present losses. A plaintiff may not sue for future projected losses; instead, she is expected to bring successive actions should such losses actually occur. Most plaintiffs are unlikely to have the desire, time, or money to bring one action after another in order to make a defendant compensate them for continued losses resulting from the contamination or its cleanup. This is another reason that the plaintiff's recovery may be incomplete.

A plaintiff who by choice or compulsion proceeds under a permanent nuisance or trespass theory suffers from two restrictions. First, since full remediation has been deemed unreasonable, the plaintiff must accept a one-time payment to compensate for the permanent presence of contamination on his or her property, an obviously undesirable result. No parent or business owner would choose to raise children or work on a site contaminated with hazardous materials whose health effects are unknown at bestand carcinogenic or otherwise dangerous at worst. Second, while a plaintiff litigating under a classification of permanent nuisance or trespass may obtain future damages, he or she is permanently estopped from bringing another action against the defendant for this contamination. The plaintiff must thus estimate in the present the amount of any future losses over the life of the property. At the moment of this calculation, the contamination is by definition less than three years old. Because the plaintiff must rush to bring a permanent nuisance or trespass claim to beat the statute of limitations, the full extent of the contamination and costs of cleanup are often uncertain and often underestimated.

III

Environmental Negligence-A Proposal for a New Cause of ACTION

Acknowledging the imperfect fit of both the statutory and common law routes for addressing environmental contamination, as well as fairness considerations and the public benefit of a clean environment, the value of a more efficient and effective solution to environmental contamination becomes clear. A new, negligence-based cause of action allows for the increased flexibility of common law claims without the limitations of nuisance and trespass. 
The idea of a new or emerging tort is not unprecedented: widely accepted causes of action such as intentional infliction of emotional distress, invasion of privacy, strict products liability, and wrongful employment discharge are all relatively recent additions to tort law. ${ }^{129}$ Conservatism, as the predominant opposition to the creation of new torts, may be overcome by approaching the new tort as merely a natural outgrowth of older established common law-an evolution of concepts rather than a revolutionary response to a modern problem. ${ }^{130}$ In addition, links to rationales in other areas of law, such as contract and property, will help promote the new tort's acceptance and avoid radical, one-sided cause advocacy. ${ }^{131}$ A modest outgrowth of negligence to address toxic contamination of property fits this bill.

\section{A. Public Policy Concerns and the Development of a More Flexible Solution}

It is in the public's best interest to see contaminated sites remediated to the full extent feasible. Society as a whole does not benefit from pollution left lingering or spreading due to legal technicalities. The short-term economic gain to former polluters who escape responsibility cannot compare to the health and environmental effects on those who follow them, or the eeonomic effects on a society that will eventually pick up the tab through increased healthcare costs and taxes. A common law cause of action offers environmental contamination plaintiffs greater flexibility and thus greater likelihood of full reeovery. It can also serve to force polluters to pay for the costs they have unfairly imposed not only on plaintiffs but also on the community in general. The development of a new common law cause of action retaining the flexibility of nuisance and trespass but specifically tailored to the problems of environmental contamination would make recovery and remediation more likely, thus serving both individual justice and public policy.

\section{B. Environmental Negligence}

Using a negligence-based claim to address environmental contamination avoids many of the limitations imposed by nuisance and trespass. A specialized form of environmental negligence might afford plaintiffs a simpler and more effective method for achieving the ultimate goal-site cleanup funded by the parties responsible for the contamination.

The use of an environmental negligence claim should serve as a companion to federal or state statutory claims. An owner of contaminated land

129. Anita Bernstein, How to Make a New Tort: Three Paradoxes, 75 TEx. L. REv. 1539, 1541

(1997).

130. Id. at $1544-47$.

131. Id. at $1548-59$. 
should utilize both the statutory and common law methods of recovery, with the common law suits used primarily to fill in the holes left by statutory causes of action like CERCLA and RCRA. Presumably, those statutes will allow the landowner to achieve some form of partial recovery. If the statutes are incapable of making the plaintiff fully whole, the common law claim of environmental negligence may function as a less complex alternative to nuisance and trespass claims for recovering damages or expenses not included in the statutory-based recovery.

Negligence provides an attractive potential source of complete recovery for several reasons, the first being its relatively basic definition. "It is hornbook law that "[a]ctionable negligence involves a legal duty to use due care, a brcach of such legal duty, and the breach as the proximate or legal cause of the resulting injury." 132 Forms of negligence have already been used to address environmental cleanup sites due to the applicability of the duty, breach, and causation requirements to acts of pollution. ${ }^{133}$ Plaintiffs have used a negligence per se cause of action based on the defendant's violation of a statute through discharge or dumping of hazardous wastes on the property. ${ }^{134}$ Another negligence-based cause of action comes in the form of breach of duty to disclose a material and concealed defect; this cause of action arises when defendant sells contaminated property to plaintiff without disclosing the presence of hazardous wastes. ${ }^{135}$

Establishing liability under a proposed tort of environmental negligence requires revisiting traditional notions of land vendor and vendee liability. Under the Restatement (Second) of Torts, caveat emptor traditionally blocks the duty of a seller of land for pre-existing conditions that later cause physical harm to the purchaser. ${ }^{136}$ An exception exists, however, for cases where a seller with actual or constructive knowledge of a condition on the land posing an unreasonable risk to persons on or off the land concealed or failed to disclose that condition. ${ }^{137}$ This exception seems to create liability for sellers who dumped toxic wastes on their land, so long as they appreciated the risks they were creating, which may or may not be provable depending on the circumstances. The Restatement also provides that if there is a condition on the land that constitutes a nuisance for which the seller would have remained liable had he retained possession, the seller remains liable for physical harm caused by that nuisance after the

132. Newhall Land \& Farming Co. v. Superior Court, 19 Cal. App. 4th 334, 349 (Cal. Ct. App. 1993) (quoting Felburg v. Don Wilson Builders, 142 Cal. App. 3d 383, 393 (Cal. Ct. App. 1983)).

133. See, e.g., id. at 347; Mangini, 230 Cal. App. 3d at 1149.

134. See, e.g., Newhall, 19 Cal. App. 4th at 347; Mangini, 230 Cal. App. 3d at 1149.

135. See Newhall, 19 Cal. App. 4th at 347.

136. Restatement (SECOND) OF ToRTs $\$ 352$. But see supra note 72 (discussing the Newhall case).

137. RESTATEMENT (SECOND) OF TORTS $§ 3353$ (1965), 373 (1965). 
sale. ${ }^{138}$ Because of these exceptions, courts may find a strong foundation on which to rest liability for land sellers who polluted the property before sale. Extension of this liability to a polluter up the chain of sale (for the case of the non-privity plaintiff) may be extended through concepts in products liability. ${ }^{139}$

Any cause of action for environmental negligence must anticipate the problem of the plaintiff who learns of the contamination, takes no steps towards remediation for years, and then attempts to extract damages from a defendant at some point in the distant future. A reasonable statute of limitations, traditionally three years from first awareness of injury for negligence causes of action, would not only "ensure fairness to defendants, . . . [but also] promote judicial efficiency . . . and . . . social stability." 140 With the passage of time come faded memories, lost or destroyed records, missing witnesses, and unidentifiable or vanished contributing parties. ${ }^{141}$ A reasonable statute of limitations achieves a balance, allowing the plaintiff to fully develop and research his or her case while also drawing a line after which a defendant can rest assured that actions long in the past will not come back to haunt him or her.

These concerns must be balanced within the special context of environmental pollution. One of the most important tools to achieve this balance is the discovery rule, which, although inapplicable to nuisance and trespass, is permitted with negligence causes of action. ${ }^{142}$ Under the discovery rule, the statute of limitations does not begin to run until the plaintiff learns or should have learned of the accrual of a cause of action. ${ }^{143}$ This would protect the plaintiff who buys land polluted by the prior owner years before the purchase, and it would protect the plaintiff who has owned land for years but who discovers only much later that the site is contaminated. This permitted delay seems especially important in the environmental context, where subterranean plumes of migrating pollutants often go undiscovered for years. Yet as soon as the plaintiff discovers the contamination-or reasonably should have discovered it-the statute of limitations will begin to run.

138. RESTATEMENT (SECOND) OF TORTS $§ 840$ A (1979).

139. Negligence-based products liability for personal-injury damages has been extended to purchasers not in direct privity with the original manufacturer. See MacPherson v. Buick, 111 N.E. 1050 (N.Y. 1916). This extension of liability is important for situations where the current landowner did not purchase the land directly from the original polluter. The MacPherson doctrine was expanded to include liability for property damages in Dunn v. Ralston Purina Co., 272 S.W.2d 479 (Tenn. Ct. App. 1954), allowing the non-privity plaintiff to recover these losses as well.

140. Lin, supra note 127 , at 755 (citing Developments in the Law-Statutes of Limitations, 63

HaRv. L. REv. 1177, 1185-86 (1950)).

141. See id.

142. Oakes v. McCarthy Co., 267 Cal. App. 2d 231, 254 (Cal. Ct. App. 1968) (commenting that in negligence actions, the statute of limitations will not begin to run until the damage to the plaitiff occurs).

143. Lin, supra note 127 , at 757 . 
A second useful tool in the environmental context is tolling of the statute of limitations; this gives plaintiffs sufficient time to thoroughly assess the contamination and develop effective solutions. Under the permanent nuisance and trespass theories, a plaintiff must often rush to complete evaluative studies and cleanup cost estimates under intense time pressure. It is a waste of resources not to allow scientists the time they need to craft a workable remediation plan. Therefore, I propose that once a plaintiff learns of the contamination on the property, the statute of limitations be tolled during ongoing evaluative testing to ensure the best possible cleanup plan. The tolling should end when the plaintiff develops a workable plan, at which time plaintiff may presumably bring an action against the defendant with a much more accurate and informed cstimate of the cleanup and testing portion of the damages sought.

ln bringing the action for environmental negligence, the plaintiff should be able to seek reimbursement only for the costs of lowering the level of contamination down to government-accepted levels and all associated costs directly and proximately caused by the polluter. The economicloss rule of torts, however, traditionally sharply limits the extent to which a negligent defendant is responsible for purely economic losses, rather than personal-injury or property losses. ${ }^{144}$ This would imply that plaintiffs cannot recover losses from disruption of business or moving expenses. Some states, notably California, have extended economic-loss recovery to negligence plaintiffs in the past, ${ }^{145}$ at one time suggesting that economic-loss recovery should be available unless it would subject the defendant to expenses widely disproportionate to the scope of the harm. ${ }^{146}$ However, the modern trend moves away from this notion, ${ }^{147}$ so it may now be difficult for environmental-negligence plaintiffs to recover for damages beyond those arising from personal injury or property damage. Even limited to those losses, however, plaintiffs would still be able to recover substantial portions of the full burden imposed on them by the contamination. In cases of fraud, concealment, or other misconduct, punitive damages should be available. Because environmental negligence claims often occur in coordination with other statutory claims such as CERCLA or RCRA, the damages or injunctive relief should be restricted to those not covered by those statutes to prevent double recovery.

In defending the claim, a defendant may assert traditional defenses, including those relating to the statute of limitations. In addition, the

144. See RESTATEMENT (THIRD) OF TORTS $\$ 8$ (Tentative Draft No. 1, 1994).

145. See, e.g., J'Aire Corp. v. Gregory, 598 P.2d 60 (Cal. 1979); Biakanja v. Irving, 320 P.2d 16 (Cal. 1958).

146. See Robert L. Rabin, Tort Recovery for Negligently Inflicted Economic Loss: A Reassessment, 37 STAN. L. REV. 1513 (1985).

147. See, e.g., Summit Fin. Holdings v. Cont'1 Lawyers Title Co., 41 P.3d 548 (Cal. 2002); Quelimane Co. v. Stewart Title Guar. Co., 960 P.2d 513 (Cal. 1998). 
defendant may estop the plaintiff's claim if the defendant disclosed the pollution's presence to the plaintiff at the time of sale. Evidence of this disclosure may be inferred from a property sale price significantly below market value, which may serve as constructive notice to the plaintiff even in the absence of actual notice, depending on the facts of the case. Defendants may also implead third-party defendants who may have contributed to the contamination of the site.

Although just an outline for an extension to negligence law, the environmental negligence cause of action may serve to ensure the law remains flexible, without the complications and limitations of nuisance and trespass claims or the restrictions of CERCLA and RCRA. Ideally, an innocent purchaser of contaminated land will be able to achieve complete recovery for contaminant cleanup through a combination of both statutory and common law claims, tailored to address the intricacies of modern environmental contamination challenges.

\section{CONCLUSION}

Modern problems of environmental contamination require a more complete solution than the originally ambitious but ultimately insufficient statutory schemes of CERCLA and RCRA. Although temporarily abandoned in the hopes of full recovery under the statutes, the common law claims of nuisance and trespass provide a common law source for innocent purchasers of polluted land to seek more complete recovery of their losses. However, despite giving plaintiffs a more flexible and permissive chance at compensation than the statutory schemes, nuisance and trespass still contain certain restrictions and limitations that make them less than ideal remedies in the environmental context.

In view of the current law's limitations, this Comment proposed a new environmental negligence cause of action tailored to hazardous-waste pollution. Ideally, the proposed environmental negligence action will be well equipped to tackle the modern challenges of contamination and will promote effective cleanup. 
